Finanse, Rynki Finansowe, Ubezpieczenia nr 5/2017 (89), cz. 2

\title{
The performance of analyst recommendations in the banking sector: A case of Poland
}

\author{
Piotr Bolibok*
}

\begin{abstract}
Purpose - The paper aims at empirical evaluation of the performance of the professional stock market analysts' recommendations in the Polish banking sector.

Design/methodology/approach - The employed research methods involve the analyses of structure and accuracy of the examined recommendations in terms of target prices. The examined sample covers 2,806 stock recommendations issued for 14 banks listed on the Warsaw Stock Exchange over the period 1999-2016. The performance of each recommendation was assessed over a time horizon of 180 days from its issuance through comparison with actual market prices of a given stock.

Findings - Consistent with the evidence in the relevant literature the results of the study indicate that even in such complex and opaque industry as banking, the analyst recommendations should serve only as a supplementary source of information supporting the decision-making processes of the equity investors. In the specific context of the Polish banking sector the analyst recommendations performed moderately, with slightly more than $56 \%$ of them being able to correctly predict the prices of bank stocks within the 180 days time window since the issuance date. However, even if the exact target prices were often not reached, the recommendations seem useful as the indicators of the short-run price movements.

Originality/value - The majority of empirical studies in the relevant literature examines the performance of analyst recommendations without taking into account the potential impact of industry-specific contextual factors. Additionally, these studies are focused mostly on developed capital markets, while the evidence for the emerging ones remains quite modest. Moreover, to date apparently no study has addressed this issue in the context of the Polish capital market. The present study attempts, therefore, to fill this gap.
\end{abstract}

Keywords: analyst recommendations, stocks, banks

\section{Introduction}

Rational investment decisions of the equity investors should be based on an in-depth analysis of the available sources of relevant information. The quantity, complexity and volatility of information reaching the capital markets significantly increase the risk related with investments. In an uncertain environment these decision-making processes might be supported with recommendations issued by the professional stock market analysts. This support should be particularly useful for investment decisions regarding highly opaque and complex industries, where the assessment of intrinsic values of stocks might be particularly difficult and burdened with higher error margins.

\footnotetext{
* Piotr Bolibok, PhD, The John Paul II Catholic University of Lublin, Al. Racławickie 14, 20-950 Lublin, Poland, e-mail: piotr.bolibok@kul.pl.
} 
The complexity and opaqueness of modern banks places them among the most difficult businesses to value (Koller et al., 2010, p. 765). Compared to other industries banks are also much more sensitive to the course of the business cycle and exposed to various risks that additionally hinders the valuation (Damodaran, 2009). The expertise of professional stock market analysts should, therefore, prove particularly valuable in the banking sector. On the other hand, however, these unfavourable conditions might inhibit the ability of analysts themselves to collect and process the value-relevant information, which in turn could decrease the accuracy of issued recommendations.

The vast majority of prior studies in the literature examines the performance of analyst recommendations without taking into account the likely impact of industry-specific contextual factors. Moreover, these studies tend to be largely focused on the developed capital markets, while the evidence for the emerging ones still remains rather modest. In particular, to author's knowledge, no prior study has investigated this issue in the context of the Polish banking sector. Given the above, the paper attempts to fill this gap by providing empirical evidence on the performance of analysts recommendations for banks' stocks in the capital market of Poland.

The remainder of the paper is organized into four sections. The next section provides a review of the relevant literature on the performance of analyst recommendation with a particular focus on the banking sector. The research design and data collection procedures are described in Section 2. The results of the study are presented and discussed in Section 3. The paper is closed with concluding remarks recapitulating its main findings and providing some suggestions on the directions of further research.

\section{The literature review}

Since the seminal study by Cowles (1933) the usefulness of stock market analyst recommendations has been thoroughly examined in the academic literature. The results of these investigations are, however, mixed. Although some studies argue that analysts' recommendations are able to provide investment returns (see e.g. Baks, Busse, 2007; Howe et al., 2009; Barber et al., 2010 or Drake et al., 2011), the majority of them concludes that recommendations have no investment value (Bradshaw, 2009, p. 1073). In particular, Chen et al. (2005) demonstrate that the impact of average analysts' consensus recommendations on stock prices is not significantly different from the average stock price movement. He et al. (2013) find that even though stocks with favourable (unfavourable) recommendations on average outperformed (underperformed) the benchmark index, after controlling for transaction costs, the investment strategy based on recommendations appears to yield no significant abnormal returns. Despite these apparent drawbacks, Kelly et al. (2012) demonstrate that analyst recommendations influence the equity investors' judgement of stock's potential, as they perceive it more favourably with a "buy" recommendation than with a "sell" one, ceteris paribus. 
Usually, even though security analysts' stock recommendations result in immediate price reactions, price drifts tend to continue in the subsequent months (see e.g. Barber et al., 2010). According to Loh (2010) these drifts might be caused by investor inattention, since low-attention stocks initially react less to recommendations than high-attention ones, but the subsequent price drift of low-attention stocks is on average more than double in magnitude. The study by Chang and Chan (2008) suggests that downward stock recommendation revisions by financial analysts' are more informative to investors than the upward ones. Moreover, the reaction of stock prices following the recommendation is determined by the magnitude of recommendation change and the reputation of the brokerage firm issuing it.

In general, the empirical evidence suggests that the informativeness of forecasts is largely dependent on the skills, experience and reputation of the analysts preparing them. The value relevance of recommendations appears to increase if they are issued by the analysts who have outperformed in the past (Mikhail et al., 2004) or by experienced analysts from reputable brokerage firms (see e.g. Sorescu, Subrahmanyam, 2006; Brown et al., 2009). Loh and Stulz (2011) find that the recommendations issued by more reputable analysts or the ones whose former recommendations had significant impact on the market or were distinctly different from the consensus are more informative. Booth et al. (2014) demonstrate that stock recommendations are more likely to direct a path for the consensus when they are issued by lead analysts simultaneously with earnings forecasts in the same direction, away from the consensus, followed by price momentum, issued on large and high growth firms, and issued by analysts from large brokers with less frequent recommendations. Several studies, however, document quite different results. According to Emery and Li (2009) the recommendations issued by the most reputable analysts are not better (and sometimes even worse) than the recommendations of others. Also Jegadeesh and Kim (2010) find that analysts from smaller brokerage houses and those who do not herd around the consensus exert a greater impact on stock prices. The proneness of analysts to herd appears to increase if they represent larger brokerage houses, follow stocks with smaller dispersion across recommendations, or make less frequent recommendation revisions.

The empirical evidence also suggests that the conflicts of interests resulting from the business or personal ties between the analysts and subject companies might significantly bias the recommendations they issue. The evidence provided by Barber et al. (2007) suggests that investment banking firms are reluctant to downgrade buy-rated stocks and thus implicitly support their former underwriting efforts. In turn, Firth et al. (2013) argue that analyst recommendations on stocks relative to consensus are significantly higher if the stock is held by the mutual fund clients of the brokerage firm issuing it. Moreover, subsequent to announcements of bad news from the covered firms, analysts seem to be much less likely to downgrade a stock held by client mutual funds. Gu et al. (2013) come to similar conclusions, finding that analysts are more optimistic in their recommendations for stocks that constitute a significant part of the investment portfolios of the fund companies from which their 
brokerages receive trading commission fees. Arand and Kerl (2015) argue, in turn, that the aggregate number of simultaneous business ties with a subject company is positively associated with optimism in target prices and recommendations. Their results, however, do not indicate that investors take conflicts of interests into account when trading on stock recommendations and target prices, which suggests that they are either unaware of these conflicts or reluctant to reject the results of analysts' research. The results of a study by Brown et al. (2014) indicate that analysts face an important conflict, as on the one hand issuing earnings forecasts and stock recommendations that are well below the consensus increases their credibility with investing clients, but at the same time it damages analysts' relationships with managers of the firms they follow.

Given the preponderance of buy recommendations, many of which turn out to be unsupported by subsequent returns, the evidence in the relevant literature suggests that on average analysts tend to be overoptimistic in their judgements of stock performance. For instance Jegadeesh et al. (2004) demonstrate that analysts generally recommend "glamour" (i.e., positive momentum, high growth, high volume, and relatively expensive) stocks. Naive adherence to such recommendations might prove particularly costly for nonprofessional and unsophisticated investors, who are more likely to follow them. This issue is explicitly evident in the light of a study by Malmendier and Shanthikumar (2007) who demonstrate that large investors tend to account for analysts' optimistic bias by not reacting to "buy" recommendations and exhibiting a tendency to sell after "hold" recommendations, while smaller ones follow recommendations literally, thus achieving lower trading returns. These findings are consistent with the results of Mikhail et al. (2007) who find that recommendations may more easily mislead small investors as the institutional ones are more sophisticated processors of information.

According to Kerl (2011) the accuracy of target price forecasts is negatively related to analyst-specific optimism and stock-specific risk (measured by volatility and $\mathrm{P} / \mathrm{BV}$ ratio) and positively related to the level of detail of each report, company size and the reputation of the investment bank. Moreover, the potential conflicts of interests between an analyst and a covered company do not seem to bias the forecast accuracy.

The issue of analysts' overoptimism seems to exist also in the Polish capital market. For instance, the results of a study by Bolibok (2008) covering the sample of over 3.5 thousand recommendations issued for 163 companies listed on the Warsaw Stock Exchange over the period 2002-2006 indicate that for more than $83 \%$ of these firms, the target prices announced in the recommendations were exceeding the current market prices. Additionally, Dąbrowski (2013) documents that during the period of highest volatility and largest recent market downturn (2007-2011) over 70\% of the stock recommendations issued for the bluechip companies listed on the WSE suggested buying stocks despite the bearish sentiments in the market, which in turn resulted in their poor performance.

As regards the banking sector, the results of a study by Devos (2014) indicate that analysts who issue recommendations for investment banks are relatively optimistic regarding 
the prospects of subject banks to which they are related through syndication. An extensive study by Premti et al. (2017), based on a sample of over 23 thousand analyst recommendations of 1,106 banks, demonstrates that both positive and negative analyst recommendations tend to be more informative for banks that are riskier and subject to a higher degree of information asymmetry. The usefulness of recommendations in the banking sector appears to increase when the information environment becomes more uncertain. In turn, Desai et al. (2016) provide some evidence on the poor performance of analyst recommendations in the banking sector prior to the recent global financial crisis. They demonstrate that even though the financial statements of the largest U.S. bank holding companies for the fourth quarter of 2006 reflected at least some of the increased risk of bank distress in advance, no significant change in analyst recommendations could be observed for over a month after their announcement.

The empirical evidence on the performance of analyst recommendations in the emerging markets remains quite modest. For instance, an investigation of Brazilian capital market by Martinez (2010) demonstrates that even if some analyst recommendations performed reasonably well in terms of market adjusted return in the period of 30 days after their issuance, the consensus recommendation did not. On the other hand, however, the sell recommendations and downgrades produced significant negative returns.

In turn, a study of Chinese capital market by Cai and Cen (2015) demonstrate that in a bear market of 2011 equity investors could not profit by following analysts' recommendations, while during a period of improving market performance (2012), a positive and stable return could be produced when following the buy or accumulate recommendations.

\section{Research design}

Given the complexity of banks' activities and a relative opaqueness of their financial reporting, the recommendations issued by the professional analysts should provide the equity investors with valuable information on the expected future performance of banks' stocks. The results of prior international and domestic studies on the performance of analyst recommendations suggest, however, their limited accuracy and usefulness for the investors. Given the above, the following hypothesis was formulated:

H1: Analysts recommendations in the banking sector should be treated only as a supplementary source of information supporting the decision-making processes of equity investors.

In order to test the above hypothesis, the analyses of structure, frequency and accuracy of analyst recommendations issued for the stocks of banks listed on the Warsaw Stock Exchange were employed.

Following Kerl (2011, p. 83), the accuracy of target price in the examined sample of analyst recommendations was assessed using the following formula: 


$$
T P A=1-\left|\frac{P_{i t}}{T P}-1\right|,
$$

where:

$T P A$ - target price accuracy,

$P_{i t}-$ closing price of the stock of bank $i$ at the end of day $t$,

$T P$ - forecasted target price.

The examined sample covered all recommendations with target prices issued in the period 1999-2016. The performance of each recommendation was assessed over the time window of 180 days following its issuance through comparison with the closing prices of a given stock in that period, after controlling for potential stock splits. The data on recommendations were collected from the Bankier.pl website (http://www.bankier.pl..., 2017), while the data on stock prices were extracted from the database of the Brokerage House of Bank Ochrony Środowiska SA (http://bossa.pl..., 2017). The final pooled sample covered 2,806 recommendations and 347,728 stock prices for 14 banks.

\section{Empirical results}

Figure 1 presents a histogram of deviations of target prices in the examined analyst recommendations from the actual stock prices on the issuance date.

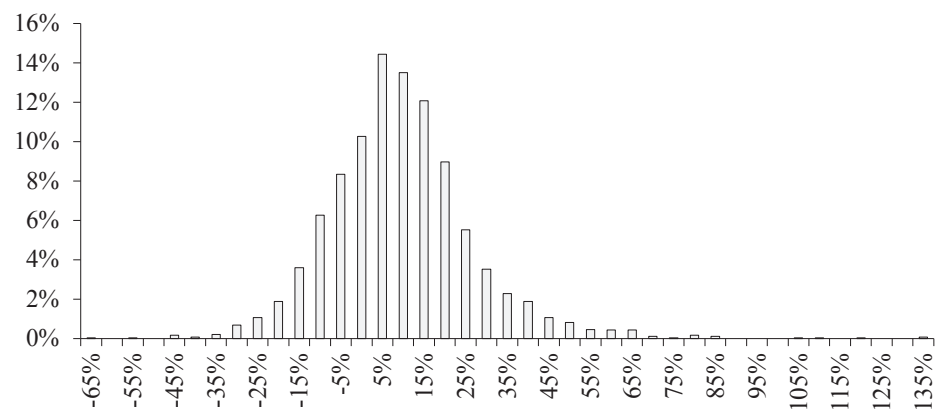

Figure 1. Histogram of target price deviations from actual stock prices on the issuance date (pooled sample)

Source: own study.

On average the target prices in the sample were $6.86 \%$ higher than the corresponding stock prices on the issuance date, with minimum of $-69.95 \%$ and maximum of $132.03 \%$. Median deviation equalled 5.96\%. The distribution of deviations was positively skewed (coefficient of skewness $=0.895$ ) and significantly leptokurtic (kurtosis $=4.099)$. These 
findings seem to indicate a slightly optimistic bias of the analysts issuing the examined recommendations.

This bias becomes even more evident, if the type of recommendation is taken into account. In this step of the analysis the examined recommendations were divided into three categories:

- "positive" ("buy", "hold", “outperform", "accumulate", "add", “over-weight"),

- "neutral" ("neutral", "balance", "market perform"),

- "negative" ("sell", "reduce", "under-weight", "high risk", "underperform"

Almost $63 \%$ of the examined recommendations contained a positive conclusion. The share of negative recommendations was almost three times lower (21\%), and only $16 \%$ were neutral (Figure 2).

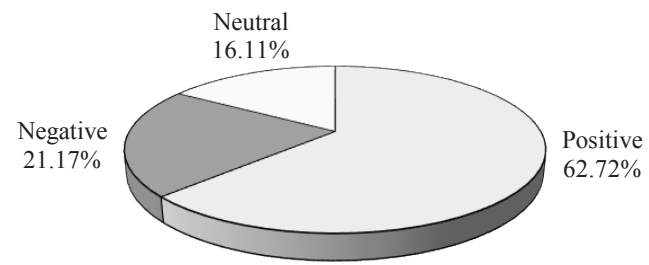

Figure 2. Structure of analyst recommendations in the pooled sample

Source: own study.

As regards the accuracy of the examined recommendations only for $56.24 \%$ of them stock prices were able to reach the target levels within 180 days from their issuance. The percentage of accurate recommendations seems to decline sharply with time. Figure 3 presents the relationship between the number of days that passed since the recommendation issuance date and the percentage of recommendations for which the closing price of stock met the target level.

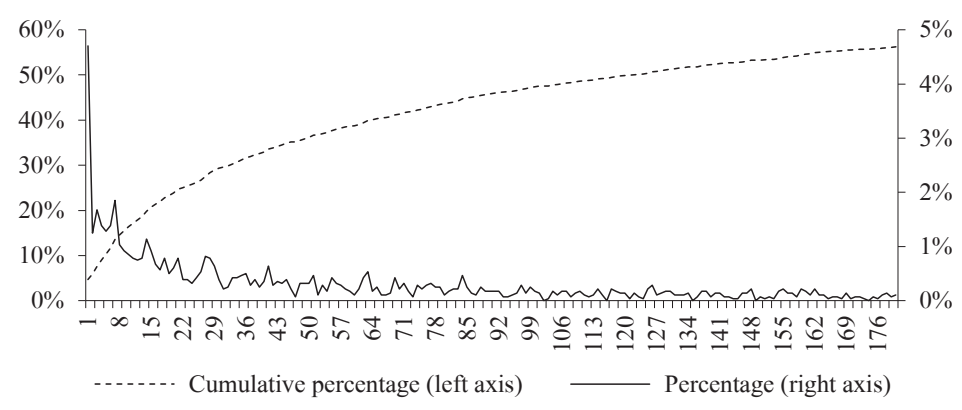

Figure 3. The number of days since the issuance date and the percentage of accurate recommendations

Source: own study. 
The probability that a recommendation turns out to be accurate sharply declines with time. In fact, for $4.7 \%$ of all recommendations ( $8.4 \%$ of the accurate ones) the target prices were met on the day following their issuance, and for more than a half (52.2\%) of accurate recommendations $(29.4 \%$ of all) this happened within the first 30 days since the issuance date.

Even though the accuracy of target price forecasts remained moderate, the issued recommendations appeared to much more in line with the succeeding stock price movements (Figure 4).

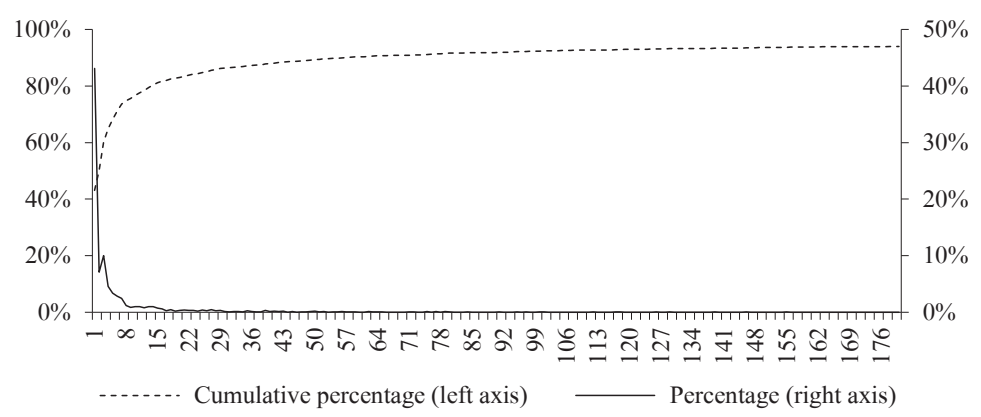

Figure 4. The number of days since the issuance date and the percentage of recommendations that were followed by a change in stock price towards the target price

Source: own study.

Over $43 \%$ of the examined recommendations were followed by a change in the stock price toward the target even within one day since their issuance. During the first 30 days an analogous reaction could be observed for over $86 \%$ of recommendations. Given the above, it might be concluded that although only slightly more than a half of analyst recommendations in the banking sector becomes accurate within their validity period, they might be used as relatively reliable indicators of short-run stock price movements.

Figure 5 presents the mean and median values of target price accuracy in the pooled sample of analyst recommendations over the time window of 180 days since the issuance date.

As expected, the accuracy of target prices in recommendations was highest at the very beginning of the analysed time window and noticeably declined with time. The median value of TPA in the first days after the issuance date fluctuated near the $90 \%$ level, and gradually declined by 8 percentage points to $81.5 \%$ after 180 days. Mean values of TPA were lower than medians in the entire analysed time window, and decreased at a clearly faster rate, starting from $87.4 \%$ and falling below $75 \%$ after 180 days. Moreover, the volatility of both mean and median values significantly increased towards the end of the analysed time window. Both these tendencies likely reflect the impact of the ongoing flow of new 
information to the capital market which gradually widens the gap between the target and actual stock prices.

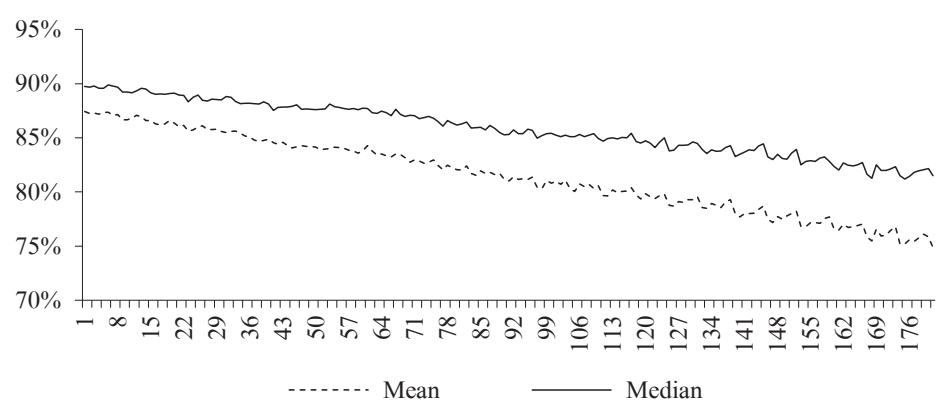

Figure 5. The number of days since the recommendation issuance date vs. mean and median values of target price accuracy (pooled sample)

Source: own study.

The results of the investigation appear to support the key hypothesis of the present study. On the one hand only slightly more than a half of the examined recommendations were able to accurately predict the prices of bank stocks within 180 days following their issuance. On the other hand, however, even if target prices are frequently not reached, the analyst recommendations appear to be quite useful indicators of the short-term stock price movements.

\section{Concluding remarks}

Consistent with the evidence in the relevant literature, the results of the research indicate that even in the banking sector which naturally appears much more complex and opaque to external stakeholders, expertise of the professional stock market analysts expressed in the form of recommendations should serve only as a supplementary source of information supporting the decision-making processes of the equity investors. Overall, in the specific context of the Polish banking sector the analyst recommendations performed moderately, as slightly more than $56 \%$ of them correctly predicted the prices of bank stocks within the 180 days time window since the issuance date. On the other hand, the findings of the study suggest that even if the exact target prices are often not reached, the analyst recommendations might prove useful as the indicators of the short-run price movements.

Given the pioneering nature of the present study, the future research might attempt to explore the issue of analyst forecast accuracy in relation to the course of the business cycle and the overall sentiments in the capital market. 


\section{References}

Arand, A., Kerl, A.G. (2015). Sell-side analyst research and reported conflicts of interest. European Financial Management, 1 (21), 20-51.

Barber, B.M., Lehavy, R., Trueman, B. (2007). Comparing the stock recommendation performance of investment banks and independent research firms. Journal of Financial Economics, 2 (85), 490-517.

Baks, K P., Busse, J.A. (2007). The importance of analysts vs. brokers in the performance of stock recommendations, Working Paper, Goizueta School of Business, Emory University.

Barber, B.M., Lehavy, R., Trueman B. (2010). Ratings changes, ratings levels and the predictive value of analysts' recommendations. Financial Management, 2 (39), 533-553.

Bolibok, P. (2008). Rekomendacje analityków a kursy akcji na Giełdzie Papierów Wartościowych w Warszawie w latach 2002-2006. Annales Unnniversitatis Mariae Curie-Skłodowska, Sectio H, Oeconomia, 42, 41-53.

Booth, L., Chang, B., Zhou, J. (2014). Which analysts lead the herd in stock recommendations? Journal of Accounting, Auditing \& Finance, 4 (29), 464-491.

Bradshaw, T. (2009). Analyst information processing, financial regulation, and academic research. The Accounting Review, 4 (84), 1073-1083.

Brown, L.D., Call, A.C., Clement, M.B., Sharp, N.Y. (2014). Inside the "black-box" of sell-side financial analysts. Journal of Accounting Research, 1 (55), 1-47.

Brown, R., Chan, H.W.H., Ho, Y.K. (2009). Analysts' recommendations: From which signal does the market take its lead? Review of Quantitative Finance and Accounting, 2 (33), 91-111.

Cai, R., Cen, Z. (2015). Can investors profit by following analysts' recommendations? An investigation of Chinese analysts' trading recommendations on industry. Economics, Management, and Financial Markets, 3 (10), 11-29.

Chang, Y., Chan, C. (2008). Financial analysts' stock recommendation revisions and stock price changes. Applied Financial Economics, 4 (18), 309-325.

Chen, Q., Francis, J., Schipper, K. (2005). The applicability of the fraud on the market presumption to analysts' forecasts," Working Paper, Duke University.

Cowles, A. III (1933). Can stock market forecasters forecast? Econometrica, 1 (3), 309-324.

Damodaran, A. (2009). Valuing financial service firms. Retrieved from: www.stern.nyu.edu/ adamodar/pdfiles/papers/finfirm09.pdf (1.02.2017).

Dąbrowski, P. (2013). Hurraoptymizm rekomendacji maklerskich w okresie giełdowej dekoniunktury. Studia Ekonomiczne, 174, 88-104.

Desai, H., Rajgopal, S., Yu, J.J. (2016). Were information intermediaries sensitive to the financial statement-based leading indicators of bank distress prior to the financial crisis? Contemporary Accounting Research, 2 (33), 576-606.

Devos, E. (2014). Are analysts' recommendations for other investment banks biased? Finance Management, 2 (43), $327-353$.

Drake, M.S., Rees, L., Swanson, E.P. (2011). Should investors follow the prophets or the bears? Evidence on the use of public information by analysts and short sellers. The Accounting Review, 1 (86), 101-130.

Emery, D.R., Li, X. (2009). Are the Wall Street analyst rankings popularity contest? The Journal of Financial and Quantitative Analysis, 2 (44), 411-437.

Firth, M., Lin, C., Liu, P., Xuan, Y. (2013). The client is king: Do mutual fund relationships bias analyst recommendations? Journal of Accounting Research, 1 (51), 165-200.

Gu, Z., Li, Z., Yang, Y.G. (2013). Monitors or predators: The influence of institutional investors on sell-side analysts. The Accounting Review, 1 (88), 137-169.

He, P.W., Grant, A., Fabre, J. (2013). Economic value of analyst recommendations in Australia: an application of the Black-Litterman asset allocation model. Accounting and Finance, 53, 441-470.

Howe, J.S., Unlu, E., Yan, X. (2009). The predictive content of aggregate analyst recommendations. Journal of Accounting Research, 3 (47), 799-821.

http://www.bankier.pl/gielda/rekomendacje (1.03.2017).

http://bossa.pl/pub/metastock/mstock/mstall.zip (1.03.2017).

Jegadeesh, N., Kim, W. (2010). Do Analysts Herd? An Analysis of Recommendations and Market Reactions. The Review of Financial Sudies, 2 (23), 900-937.

Jegadeesh, N., Kim, J., Krische, S.D., Lee, C.M.C. (2004). Analyzing the analysts: When do recommendations add value? The Journal of Finance, 3 (59), 1083-1124. 
Kelly, K., Low, B., Tan, H.-T., Tan, S.-K. (2012). Investors' reliance on analysts' stock recommendations and mitigating mechanisms for potential overreliance. Contemporary Accounting Research, 3 (29), 991-1012.

Kerl, A.G. (2011). Target price accuracy. Official Open Access Journal of VHB, 1 (4), 74-96.

Koller, T., Goedhart, M., Wessels, D. (2010). Valuation. Measuring and Managing the Value of Companies, $5^{\text {th }}$ ed., New Jersey: John Wiley \& Sons.

Loh, R.K. (2011). Investor inattention and the underreaction to stock recommendations. Financial Management, 3 (39), 1223-1252.

Loh, R.K., Stulz, R.M. (2011). When are analyst recommendation changes influential? The Review of Financial Studies, 2 (24), 593-627.

Malmendier, U., Shanthikumar, D. (2007). Are small investors nave about incentives? Journal of Financial Economics 2 (85): 457-489.

Martinez, A.L. (2010). Analysts recommendations and stock performance: An empirical study of Brazilian public companies. Advances in Scientific and Applied Accounting, 1 (3), 90-108.

Mikhail, M.B., Walther, B.R., Willis, R.H. (2004). Do security analysts exhibit persistent differences in stock picking ability? Journal of Financial Economics, 1 (74), 67-91.

Mikhail, M.B., Walther, B.R., Willis, R.H. (2007). When security analysts talk, who listens? The Accounting Review, 5 (82), 1227-1253.

Premti, A., Garcia-Feijoo, L., Madura, J. (2017). Information content of analyst recommendations in the banking industry. International Review of Financial Analysis, 49, 35-47.

Sorescu, S., Subrahmanyam, A. (2006). The cross section of analyst recommendations. Journal of Financial and Quantitative Analysis, 1 (41), 139-168.

\title{
SKUTECZNOŚĆ REKOMENDACJI ANALITYKÓW W SEKTORZE BANKOWYM: PRZYPADEK POLSKI
}

\begin{abstract}
Abstrakt: $\mathrm{Cel}$ - Celem artykułu jest weryfikacja empiryczna skuteczności rekomendacji analityków giełdowych w polskim sektorze bankowym.

Metodologia badania - Zastosowane metody badawcze obejmują analizę struktury rekomendacji oraz tendencji w zakresie ich dokładności z punktu widzenia wskazywanych docelowych cen akcji. Próba badawcza objęła 2.806 rekomendacji giełdowych wydanych dla 14 banków notowanych na Giełdzie Papierów Wartościowych w Warszawie w okresie 1999-2016. Wyniki każdej rekomendacji zostały ocenione w 180-dniowym horyzoncie czasowym od daty jej wydania poprzez porównanie z bieżącymi cenami akcji.

Wynik - Uzyskane wyniki są zgodne z rezultatami poprzednich badań w literaturze przedmiotu i wskazują, że nawet w przypadku tak złożonego i mało transparentnego sektora jak bankowy, rekomendacje analityków powinny służyć jedynie jako uzupełniające źródło informacji wspierających procesy decyzyjne inwestorów giełdowych. W specyficznym kontekście polskiego sektora bankowego, rekomendacje analityków cechowały się umiarkowaną skutecznością - nieco ponad 56\% z nich było w stanie trafnie przewidzieć cenę akcji banków w horyzoncie 180 dni od daty wydania. Pomimo, iż wskazane ceny docelowe często nie były osiągane, rekomendacje wydają się jednak przydatne jako wyznaczniki kierunków krótkoterminowych ruchów cen akcji.

Oryginalność/wartość - Większość badań empirycznych w literaturze przedmiotu analizuje skuteczność rekomendacji analityków bez uwzględniania potencjalnego wpływu specyficznych dla danego sektora czynników kontekstualnych. Dodatkowo, badania te koncentrują się głównie na rozwiniętych rynkach kapitałowych, podczas gdy stosunkowo nieliczne opracowania dotyczą rynków wschodzących. W szczególności żadne $\mathrm{z}$ dotychczasowych badań nie analizowało powyższego zagadnienia w kontekście polskiego rynku kapitałowego. Niniejszy artykuł zmierza zatem do wypełnienia zidentyfikowanej luki.
\end{abstract}

Słowa kluczowe: rekomendacje analityków, akcje, banki

\section{Citation}

Bolibok, P. (2017). The performance of analyst recommendations in the banking sector: A case of Poland. Finanse, Rynki Finansowe, Ubezpieczenia, 5 (89/2), 25-35. DOI: 10.18276/frfu.2017.89/2-02. 